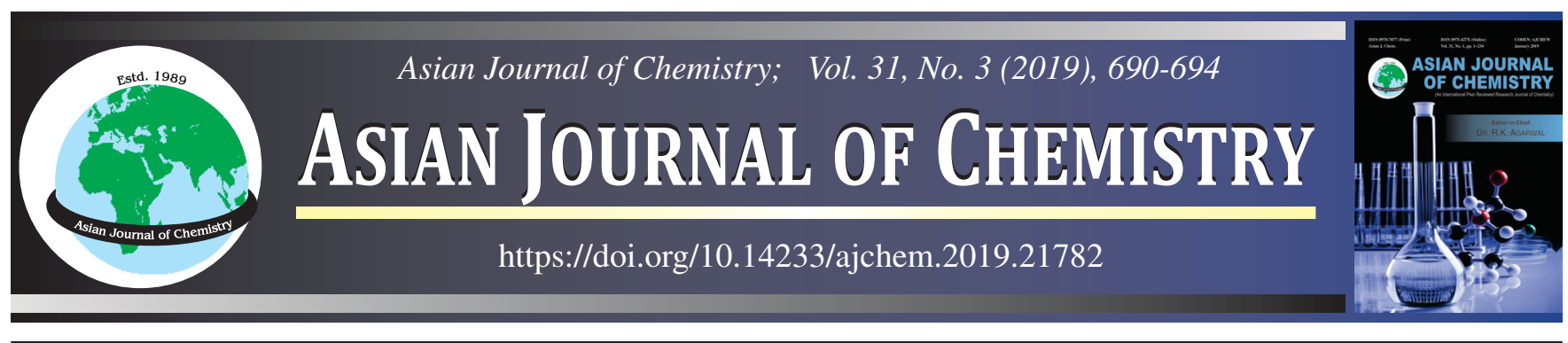

\title{
Catalytic Hydrothermal Liquefaction of Microalgae using Fe-MCM 41 Catalyst in Presence of Carbon Monoxide
}

\begin{abstract}
R. Sharma ${ }^{1, *}$, A.K. Tiwari ${ }^{2}$, A. Singh ${ }^{3}$ and N. Sharma ${ }^{1}$
${ }^{1}$ Department of Biotechnology, Uttaranchal College of Applied and Life Science, Uttaranchal University, Dehradun-248007, India ${ }^{2}$ Centre for Renewable Energy \& Sustainable Development, VIKALP (Nai Dishayen), A1/266, Safdarjung Enclave, New Delhi-110029, India ${ }^{3}$ Department of Chemistry, Uttaranchal College of Applied and Life Science, Uttaranchal University, Dehradun-248007, India

*Corresponding author: E-mail: er.rohitbiotech83@gmail.com

Received: 29 October 2018;

Accepted: 6 December 2018;

Published online: 31 January 2019;

AJC-19270

Among the various types of biomass, microalgae have a potential to become a significant energy source for the production of third generation biofuel. The hydrothermal liquefaction is the direct biomass-to-liquid conversion route carried out in the hot compressed water with or without the presence of a catalyst. In this study, the process pressure and temperature is reduced, but at a lower temperature, biooil yield is not high enough to make hydrothermal liquefaction an economical technique. Thus, Fe-MCM 41 catalyst was used to increase the bio-oil yield at low temperatures $\left(250{ }^{\circ} \mathrm{C}\right)$. This catalyst increased the total bio-oil yield from 42.7 to $61.28 \%$ in hydrothermal liquefaction of Chlorella pyrenoidosa. The bio-oil yield (\%) of oil $1,2 \& 3$ were $24.72,17.08 \& 19.48$, respectively obtained at $250{ }^{\circ} \mathrm{C}$ by using catalyst. Moreover, use of catalyst also resulted in the decrease in oxygen and nitrogen contents of bio-oil and consequently increases in its heating value.

Keywords: Bio-oil, Hydrothermal liquefaction, Fe-catalyst, Chlorella pyrenoidosa, Catalytic conversion.
\end{abstract}

\section{INTRODUCTION}

Microalgae plays a key role as a feedstock for bio-oil production and also have drawn a great attention from both research and industrial point of view [1]. Microalgae for biofuel production have several advantages over other types of biomass, including fast growth rate, wastewater treatment, higher lipid content and ability to sequester carbon dioxide from flue gas. Moreover, drying of biomass can increases the production cost of biofuel. In this interact, hydrothermal liquefaction (HTL) has been observed as a stimulating conversion method for biofuels production from microalgae which is carried out without the need of drying the biomass [2,3]. The bio-oil obtained from hydrothermal liquefaction process is known as the alternative for petroleum to produce transportation fuels and extraction of valuable chemicals in the industry [4].

Hydrothermal liquefaction is one of the main processes for bio-oil production in which the reaction of biomass in water at elevated temperature $\left(200-370^{\circ} \mathrm{C}\right)$ and high pressure $(2-20$ $\mathrm{MPa}$ ) with or without using a catalyst is done [5]. Hydrothermal liquefaction does not require dewatering and drying steps and therefore, it is suitable for processing aquatic biomass and this reduces the cost of production of bio-oil. But hydrothermal liquefaction require more expensive and elaborated safety systems with trained manpower [6]. The characteristics of biooil can be improved by two methods: one approach is catalytic hydrothermal processing with homogeneous catalysts such as alkali catalysts or organic acids [7-9]; whereas another is heterogeneous catalysts such as alkalis, and metal salts, zeolite or supported metal catalysts $[10,11]$. Use of catalysts in hydrothermal liquefaction process can increase the bio-oil yield of microalgae [7-9]. Biller et al. [10] confirmed heterogeneous catalysts in hydrothermal liquefaction process $(\mathrm{Co} / \mathrm{Mo}, \mathrm{Ni} / \mathrm{Al}$ and $\mathrm{Pt} /$ $\mathrm{Al}$ ) and concluded that the heterogeneous catalysts results in the higher heating value and the level of de-oxygenation, with improved bio-oil yields. Heterogeneous catalysts attained also significant in de-nitrogenation levels in bio-oil [11].

MCM-41 was used in catalytic hydrothermal liquefaction (HTL) of Dunaliella tertiolecta for the production of bio-oil [12]. Moreover, $\mathrm{Fe}_{2} \mathrm{O}_{3} / \mathrm{MCM}-41$ magnetic catalyst was synthe-

This is an open access journal, and articles are distributed under the terms of the Creative Commons Attribution-NonCommercial-ShareAlike 4.0 (CC BY-NC-SA 4.0) International License which allows readers to freely read, download, copy, distribute, print, search, or link to the full texts of its articles and to use them for any other lawful non-commercial purpose as long as the original source is duly acknowledged. 
sized in a facile, reproducible route and used for hydrothermal liquefaction of microalgae along with deoxygenation upgrading of derived bio-oil in absence of hydrogen [13]. Metalsubstituted MCM-41 has highest possibility for oil with less oxygen and nitrogen content compared to other catalyst. Moreover, carbon monoxide $(\mathrm{CO})$ is a better process gas for catalytic hydrothermal liquefaction, whereas $\mathrm{H}_{2}$ is found to be better process gas for non-catalytic hydrothermal liquefaction [14]. Different catalysts were used for hydrothermal liquefaction of Chlorella pyrenoidosa as reviewed in Table-1.

\section{TABLE-1}

BIO-OIL YIELD FROM DIFFERENT REACTIONS

\begin{tabular}{ccccc}
\hline Temp. $\left({ }^{\circ} \mathrm{C}\right)$ & Time $(\mathrm{min})$ & Yield $(\%)$ & Catalyst & Ref. \\
\hline 280 & 120 & 39.4 & No cat & {$[15]$} \\
$240-280$ & 30 & 52.0 & NaOH & {$[16]$} \\
300 & 20 & 50.0 & Ce/HZSM & {$[17]$} \\
\hline
\end{tabular}

\section{EXPERIMENTAL}

Microalgae: The microalgae species Chlorella pyrenoidisa was purchased from National Collection of Industrial Microorganisms (NCIM), National Chemical Laboratory (NCL) Pune, India. Chlorella pyrenoidisa was selected in this research because of its high lipid content, high growth rate, and the ability to grow in fresh water as well as in wastewater. Chlorella pyrenoidosa was one of the best oil producer microalgae, with the total lipid content of $51 \%$ of dry biomass [18]. The proximate and ultimate analysis of Chlorella pyrenoidosa is listed in Table-2. The proximate analysis was carried out by the ASTM D3172-13 and Ultimate analysis (CHNSO) was determined by a Flash 2000 CHNS/O Organic Elemental Analyser (Thermo Scientific). Higher heating value (HHV) of microalgae, solid residue and bio-oil was calculated by using Dulong's formula (eqn. 1) [19].

$$
\mathrm{HHV}(\mathrm{MJ} / \mathrm{kg})=0.338 \mathrm{C}+1.428\left(\mathrm{H}-\frac{\mathrm{O}}{8}\right)+0.95 \mathrm{~S}
$$

\section{TABLE-2}

CHARACTERISTICS OF MICROALGAE Chlorella pyrenoidisa

\begin{tabular}{|c|c|c|c|c|c|c|}
\hline \multicolumn{7}{|c|}{ Weight $\%$ (on air dried basis) } \\
\hline \multicolumn{2}{|c|}{ Moisture content } & Volatile matter & \multicolumn{2}{|c|}{ Ash content } & & ked carbon \\
\hline \multicolumn{2}{|c|}{3.1} & 80.5 & \multicolumn{2}{|c|}{3.7} & & 12.7 \\
\hline \multicolumn{7}{|c|}{ Elemental composition (on dry basis) in wt $\%$} \\
\hline Carbon & Hydrogen & Nitrogen & Sulphur & Oxy & & $\begin{array}{c}\mathrm{HHV} \\
(\mathrm{MJ} / \mathrm{Kg})\end{array}$ \\
\hline 51.91 & 11.18 & 8.79 & 0 & & & 37.53 \\
\hline
\end{tabular}

Catalyst: Fe-MCM 41 was employed as a catalyst in this research. MCM-41 is a favourable catalyst support in liquid phase reactions because of its well-defined mesoporous structure in combination with a high surface area [14,20]. The introduction of microporous catalysts like MCM-22, HZSM-22, HZSM-5, $\mathrm{H}$ beta and SAPO-11 with high hydrothermal stability improve the bio-oil quality as well as accelerate the rate of hydrothermal reaction. Fe-MCM-41 was synthesized and characterized by FT-IR spectrometer.

Sodium meta-silicate $(28.42 \mathrm{~g})$ was dissolved in $50 \mathrm{~mL}$ of distilled water taken in a polypropylene bottle and stirred for $30 \mathrm{~min}$. Then $0.202 \mathrm{~g}$ of ferric nitrate (initial gel Si/Fe ratio $=198)$ which were dissolved in $10 \mathrm{~mL}$ distilled water, were added dropwise to the mixture and kept for stirring for $1 \mathrm{~h}$. Sulphuric acid $(80 \mathrm{~mL}, 2 \mathrm{~N})$ were added drop wise to maintain the $\mathrm{pH}$ of the solution around 10-11 kept for $2 \mathrm{~h}$ stirring which becomes the solution into gel form. Further, $6.728 \mathrm{~g}$ of cetyltrimethyl ammonium bromide dissolved in $20 \mathrm{~mL}$ distilled water were added drop wise to gel and kept for $2 \mathrm{~h}$ stirring. Then the solution was transferred into autoclave and kept at $150{ }^{\circ} \mathrm{C}$ for $48 \mathrm{~h}$ in hot air oven. After $48 \mathrm{~h}$, the autoclave was allowed to cool naturally. The solution was filtered and washed with distilled water till the $\mathrm{pH}$ becomes 10 . The samples were dried at $110^{\circ} \mathrm{C}$ for $4 \mathrm{~h}$ in hot air oven. The calcination process was done at $550{ }^{\circ} \mathrm{C}$ for $6 \mathrm{~h}$.

FT-IR spectra were recorded in air at room temperature on a Perkin Elmer MB104 spectrometer in KBr pellets. The FT-IR spectrum (Fig. 1) of MCM-41 shows the stretching vibrating absorption peaks of $\mathrm{O}-\mathrm{H}$ band in the surfaced hydroxyl consists of a band of terminal silanol groups and in the planar water is seen at $3440 \mathrm{~cm}^{-1}$. The symmetry and asymmetry flexural vibrating peaks of Si-O-Si at 1,180, 812 and $464 \mathrm{~cm}^{-1}$, respectively, are related to the framework of silicon [21].

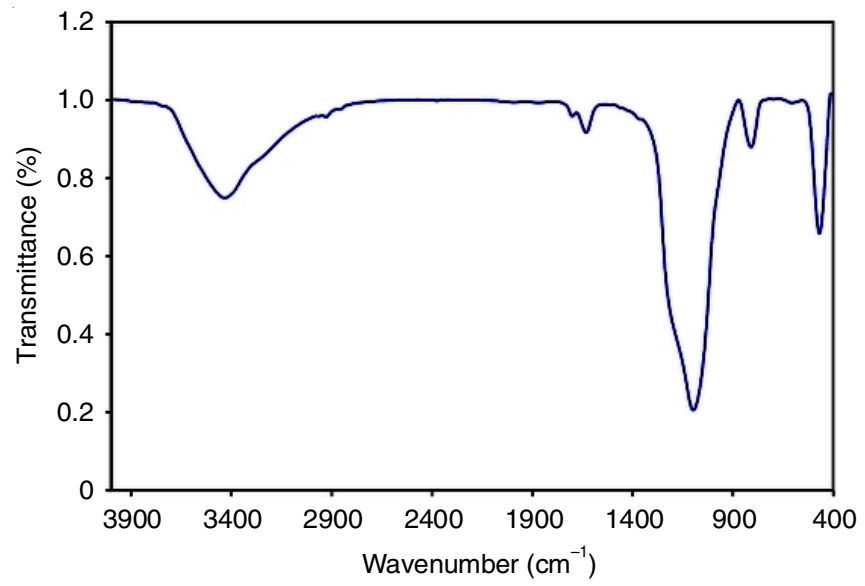

Fig. 1. FTIR spectra of Fe-MCM-41

Hydrothermal liquefaction reactor: The hydrothermal liquefaction was carried out in a micro reactor of $100 \mathrm{~mL}$ stainless steel high temperature pressure reactor (BR 100 Berghof) with a magnetic stirrer. The flow diagram of the reactor with tubing and high pressure gas regulator is shown in Fig. 2. The reactor was heated by an external electrical furnace and the temperature was measured by a thermocouple and controlled within $\pm 10^{\circ} \mathrm{C}$.

Experimental procedure: The hydrothermal liquefaction experiment was carried out in reactor of a volume of $100 \mathrm{~mL}$ stainless steel high temperature pressure reactor. Earlier to the reaction, $70 \%$ of volume of reactor was filled with a microalgaewater mixture (mass ratio 1:10) and $1 \mathrm{~g}$ of catalyst. Thereafter, the reactor was flushed with nitrogen to eliminate the air present inside. Following this, reactor was loaded with an initial pressure of 45 bar of carbon monoxide to ensure that enough pressure was provided to the system to maintain water in a liquid state throughout the heating process and the reaction. The reactor were then tightly closed and placed in a magnetic stirrer with heating 


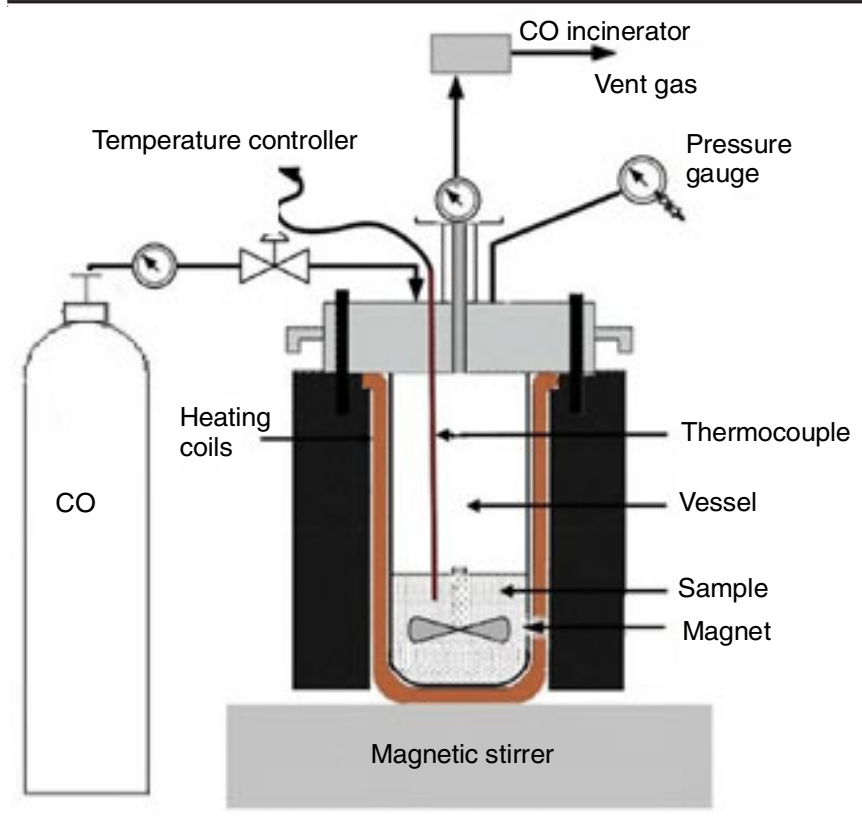

Fig. 2. Flow diagram of high temperature pressure reactor

coils connected with temperature controller, which allowed an easy control of the temperature. Reactants were agitated by magnetic stirring at $1400 \mathrm{rpm}$. The reaction was carried out at $250^{\circ} \mathrm{C}$ and pressure of 90 bars during $0.5 \mathrm{~h}$. The reaction time started once the content inside the reactor attained the desired $250{ }^{\circ} \mathrm{C}$ (measured by a thermocouple). The preceding heating took around $25 \mathrm{~min}$, which corresponded to a heating rate of $10^{\circ} \mathrm{C} \mathrm{min}{ }^{-1}$. This experiment was carried out twice to assess the reproducibility of the data.

After $0.5 \mathrm{~h}$, the reactor was kept for cooling to room temperature. Once the reactor was cooled to room temperature, carbon monoxide was removed from the reactor with the help of vent pipe through $\mathrm{CO}$ incinerator. The remaining hydrothermal liquefaction products (biocrude oil, aqueous phase and solid residue) were thereafter recovered from the interior of the reactor.

The product mixture and aqueous slurry was separated into oil 1 (ether extract), oil 2 (ethyl acetate extract), oil 3 (acetone extract of solid) and residue, by following the procedure reported by Karagoz et al. [22]. As the present study involves water insoluble catalyst unlike Karagoz et al. [22], residue included the spent catalyst and hence the residue was burnt at $500{ }^{\circ} \mathrm{C}$ for $30 \mathrm{~min}$ to get the ash content and then yield of solid residue (SR) was obtained by subtracting the ash content from the residue. The $\%$ yields of bio-oils, $\%$ conversion, $\%$ yield of solid residue and $\%$ biomass conversion to bio-oil, were calculated as per the following equations:

Yield of oil $1(\%)=\frac{\text { Weight of oil } 1}{\text { Mass of dried microalgae }(\mathrm{g})} \times 100$

Yield of oil $2(\%)=\frac{\text { Weight of oil } 2}{\text { Mass of dried microalgae }(\mathrm{g})} \times 100$

Yield of oil $3(\%)=\frac{\text { Weight of oil } 3}{\text { Mass of dried microalgae }(\mathrm{g})} \times 100$

Yield of oil SR $(\%)=\frac{\text { Weight of oil SR }}{\text { Mass of dried microalgae }(\mathrm{g})} \times 100(5)$
Yield of total oil $(\%)=\frac{\text { Weight of oil }(1+2+3)}{\text { Mass of dried microalgae }(g)} \times 100(6)$

$$
\text { Conversion }(\%)=100-\% \text { Yield of SR }
$$

Catalyst recovery: After the hydrothermal liquefaction process, it is necessary to recover the catalyst especially if the catalyst is costly. In this work, recovery of Fe-MCM41 catalyst from the solid residue was conducted. Solid residue is one of the products in hydrothermal liquefaction process of the microalgae. Since this hydrothermal liquefaction experiment is conducted at low temperatures, there is a possibility that the solid residue still contains hydrocarbons. After extracting oil 3 from solid residue, the solid residue was burnt for the process of catalyst recovery. After burning the solid residue, solid catalysts was retained, catalyst particles can be separated and recovered from the ash.

The reaction runs were performed in duplicates for with and without catalyst to ensure the repeatability of the results. The maximum deviation between the yields of products obtained in the duplicate runs was within $3 \%$, and the values reported are the average of these.

\section{RESULTS AND DISCUSSION}

Bio-oil yield: The bio-oil yield is basically the mass of bio-oil divided by the mass of dried algae (eqn. 2). Fig. 3 shows the bio-oil yields oil 1, oil 2 and oil 3 at $250^{\circ} \mathrm{C}$ with Fe-MCM 41 catalyst as well as the blank experiment where no catalyst was applied. For blank experiment, bio-oil yields of oil 1, oil 2 and oil 3 were $16.8,11.3$ and $14.6 \%$, respectively. The yield of oil 1 was found to be more as compare to oil 3 and oil 2 . The same trend was found in the catalytic experiment where a biooil yield of oil 1 was more as compare to oil 3 and oil 2 as shown in Fig. 3. For the catalytic experiment, bio-oil yields of oil 1, oil 2 and oil 3 were 24.72, 17.08 and $19.48 \%$, respectively.

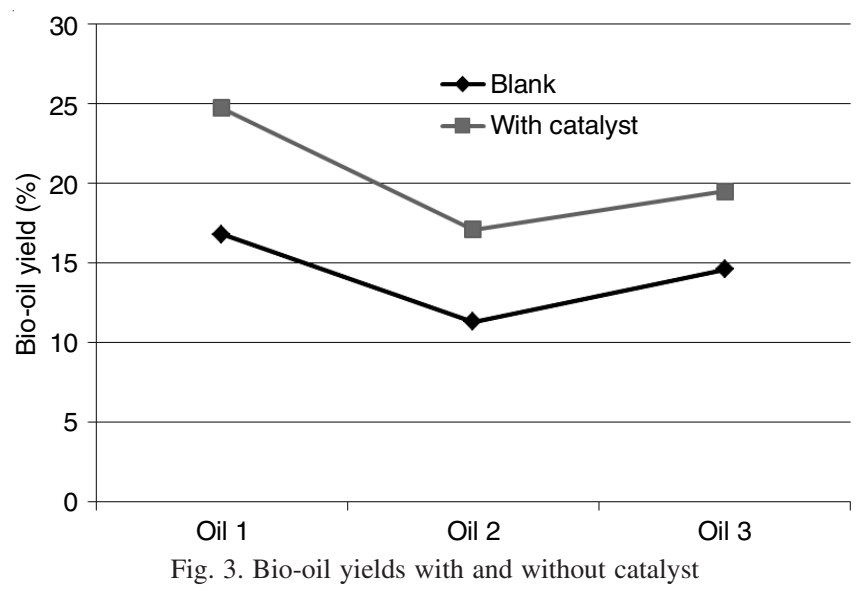

Previous works on the hydrothermal liquefaction of Chlorella pyrenoidosa have shown that the catalysts can generally increase the bio-oil yield as summarized in Table-1. However, the biooil yield in the catalytic experiment was found to be more than that of the blank or non-catalytic experiment at $250{ }^{\circ} \mathrm{C}$ [10].

Elemental composition and high heating value of biooils: The ultimate analysis, atomic ratios and high heating value of bio-oil produced at $250{ }^{\circ} \mathrm{C}$ without using catalyst and with 
TABLE-3

ELEMENTAL COMPOSITION AND HIGH HEATING VALUE OF THE BIO-OIL (WITH AND WITHOUT CATALYST)

\begin{tabular}{|c|c|c|c|c|c|c|c|c|c|c|c|c|}
\hline \multirow{3}{*}{ Bio-oil } & \multicolumn{6}{|c|}{ Without catalyst } & \multicolumn{6}{|c|}{ With catalyst (Fe-MCM 41) } \\
\hline & \multirow{2}{*}{$\begin{array}{l}\text { Weight } \\
\text { of bio- } \\
\text { oil (g) }\end{array}$} & \multicolumn{4}{|c|}{ Elemental composition (\%) } & \multirow{2}{*}{$\begin{array}{c}\text { HHV } \\
(\mathrm{MJ} / \mathrm{Kg})\end{array}$} & \multirow{2}{*}{$\begin{array}{l}\text { Weight } \\
\text { of bio- } \\
\text { oil (g) }\end{array}$} & \multicolumn{4}{|c|}{ Elemental composition (\%) } & \multirow{2}{*}{$\begin{array}{c}\mathrm{HHV} \\
(\mathrm{MJ} / \mathrm{Kg})\end{array}$} \\
\hline & & $\mathrm{N}$ & $\mathrm{C}$ & $\mathrm{H}$ & $\mathrm{O}$ & & & $\mathrm{N}$ & $\mathrm{C}$ & $\mathrm{H}$ & $\mathrm{O}$ & \\
\hline Oil 1 & 0.4050 & 1.30 & 55.30 & 25.03 & 18.37 & 51.20 & 0.618 & 0.41 & 62.71 & 27.59 & 9.29 & 58.99 \\
\hline Oil 2 & 0.3110 & 2.31 & 51.90 & 23.02 & 22.77 & 46.39 & 0.427 & 0.74 & 61.23 & 26.25 & 11.78 & 56.13 \\
\hline Oil 3 & 0.3515 & 1.22 & 48.31 & 27.05 & 23.42 & 50.81 & 0.487 & 0.59 & 57.43 & 29.32 & 12.66 & 59.07 \\
\hline
\end{tabular}

catalyst (Fe-MCM 41) are listed in Table-3. The carbon and hydrogen content of all three bio-oils from catalytic hydrothermal liquefaction were more than those of the reaction without catalyst. The oxygen and nitrogen contents of bio-oil from the catalytic hydrothermal liquefaction were less than reaction without catalyst or blank experiment $[23,24]$. The heating value of the bio-oil was in the range of 56.13 to $59.07 \mathrm{MJ} / \mathrm{Kg}$ which was higher than that of the blank experiment (46.39 to $51.20 \mathrm{MJ} /$ $\mathrm{Kg}$ ) as a result of a lower oxygen content.

Percentage conversion: From the hydrothermal liquefaction of Chlorella pyrenoidosa, the total yield of bio-oil was found to be $1.07 \mathrm{~g}$ in blank reaction and $1.53 \mathrm{~g}$ in reaction with catalyst. The production of oil 2 was low in both the reactions as compared to oil 1 from run 3 . The remaining portion of oil products (oil 3) was obtained from the acetone extraction of the solid residue. The weight of solid residue of $1.25 \mathrm{~g}$ in blank reaction and $0.79 \mathrm{~g}$ in reaction with catalyst was obtained. This is due to the increase in bio-oils yield with the influence of catalyst [22]. The solid residue was calcination at $550^{\circ} \mathrm{C}$ for $6 \mathrm{~h}$ for the recovery of catalyst. In this reaction, $55 \%$ of the catalyst was recovered from solid residue. The decrease of percentage yield of solid residue was achieved from $50 \%$ in blank to $31.6 \%$ with catalyst at $250{ }^{\circ} \mathrm{C}$ for $0.5 \mathrm{~h}$. This increased the percentage conversion from $50 \%$ to $68.4 \%$ with the used of Fe-MCM 41 catalyst [25].

\section{Conclusion}

In this article, the catalytic hydrothermal liquefaction of Chlorella pyrenoidosa was carried out at $250^{\circ} \mathrm{C}$. Fe-MCM 41 catalyst was used to investigate its effects on the bio-oil yield and its composition. The major result of this work was higher bio-oil yields and biomass conversion to bio-oil with less percentage of oxygen. The bio-oil yield was found to be increased by adding Fe-MCM 41 catalyst Chlorella pyrenoidosa. FeMCM 41 catalyst was also recovered from the solid residue. The trend of bio-oil yield was found to be oil $1>$ oil $3>$ oil 2 . This trend of bio-oil yield was same in both hydrothermal liquefaction of Chlorella pyrenoidosa with Fe-MCM 41 catalyst and without catalyst. The highest total bio-oil yield of $61.28 \%$ was obtained at $250{ }^{\circ} \mathrm{C}$ by using Fe-MCM 41 catalyst, whereas total bio-oil yield of $42.7 \%$ was obtained at $250{ }^{\circ} \mathrm{C}$ without catalyst.

For the catalytic experiment, oxygen and nitrogen contents of bio-oil for all types of oil were less than that of without catalyst experiment. The heating value was higher for all biooil produced by the catalytic hydrothermal liquefaction. The output of this research represent that using Fe-MCM-41 catalyst can increase the bio-oil yield at low temperatures by decreasing its oxygen and nitrogen contents which makes the possibility for commercialization of hydrothermal liquefaction at low temperature and pressure.

\section{ACKNOWLEDGEMENTS}

The authors thank Ministry of New and Renewable Energy, Government of India, for sanctioning project to University of Petroleum and Energy Studies, Dehradun, India. This study was peformed using consumables for micro reactor and elemental analyser sanctioned under that project.

\section{CONFLICT OF INTEREST}

The authors declare that there is no conflict of interests regarding the publication of this article.

\section{REFERENCES}

1. D. López Barreiro, S. Riede, U. Hornung, A. Kruse and W. Prins, Algal Res., 12, 206 (2015); https://doi.org/10.1016/j.algal.2015.08.025

2. L. Garcia Alba, C. Torri, C. Samorì, J. van der Spek, D. Fabbri, S.R.A. Kersten and D.W.F.W. Brilman, Energy Fuels, 26, 642 (2012); https://doi.org/10.1021/ef201415s.

3. P. Biller, A.B. Ross, S.C. Skill, A. Lea-Langton, B. Balasundaram, C. Hall, R. Riley and C.A. Llewellyn, Algal Res., 1, 70 (2012); https://doi.org/10.1016/j.algal.2012.02.002.

4. S.N. Xiu and A. Shahbazi, Renew. Sustain. Energy Rev., 16, 4406 (2012); https://doi.org/10.1016/j.rser.2012.04.028.

5. D.L. Barreiro, W. Prins, F. Ronsse and W. Brilman, Biomass Bioenergy, 53, 113 (2013); https://doi.org/10.1016/j.biombioe.2012.12.029.

6. $\quad$ S.S. Toor, L. Rosendahl and A. Rudolf, Energy, 36, 2328 (2011); https://doi.org/10.1016/j.energy.2011.03.013.

7. U. Jena, K.C. Das and J.R. Kastner, Appl. Energy, 98, 368 (2012); https://doi.org/10.1016/j.apenergy.2012.03.056.

8. T. Minowa, S. Yokoyama, M. Kishimoto and T. Okakura, Fuel, 74, 1735 (1995);

https://doi.org/10.1016/0016-2361(95)80001-X.

9. S.P. Zou, Y.L. Wu, M.D. Yang, I. Kaleem, L. Chun, J.M. Tong, Energy, 35, 06 (2010).

10. P. Biller, R. Riley and A.B. Ross, Bioresour. Technol., 102, 4841 (2011); https://doi.org/10.1016/j.biortech.2010.12.113.

11. P.G. Duan and P.E. Savage, Ind. Eng. Chem. Res., 50, 52 (2011); https://doi.org/10.1021/ie100758s.

12. Y. Chen, Y. Wu, R. Ding, P. Zhang, J. Liu, M. Yang and P. Zhang, Biofuels Food, 61, 1118 (2015).

13. J. Bian, Q. Zhang, P. Zhang, L. Feng and C. Li, Catal. Today, 293-294, 159 (2017); https://doi.org/10.1016/j.cattod.2017.02.008.

14. G. Govindasamy, R. Sharma and S. Subramanian, Biofuels, (2018); https://doi.org/10.1080/17597269.2018.1433967.

15. G. Yu, Y. Zhang, L. Schideman, Z. Wang, T. L. Funk, Trans. ASABE, 54, 239 (2011); https://doi.org/10.13031/2013.36241.

16. G. Yu, Y.H. Zhang, B. Guo, T. Funk and L. Schideman, BioEnergy Res., 7, 1317 (2014); https://doi.org/10.1007/s12155-014-9471-3. 
17. Y.F. Xu, X.J. Zheng, H.Q. Yu and X.G. Hu, Bioresour. Technol., 156, 1 (2014); https://doi.org/10.1016/j.biortech.2014.01.010.

18. A. Liu, W. Chen, L. Zheng and L. Song, Progr. Nat. Sci.: Mater. Int., 21, 269 (2011);

https://doi.org/10.1016/S1002-0071(12)60057-4.

19. T.M. Brown, P.G. Duan and P.E. Savage, Energy Fuels, 24, 3639 (2010); https://doi.org/10.1021/ef100203u.

20. J.S. Choi, D.J. Kim, S.H. Chang and W.S. Ahn, Appl. Catal. A Gen., 254, 225 (2003); https://doi.org/10.1016/S0926-860X(03)00485-X.

21. X. Song, P. Qu, N. Jiang, H. Yang and G. Qiu, Colloids Surf. A Physicochem. Eng. Asp., 313-314, 193 (2008); https://doi.org/10.1016/j.colsurfa.2007.05.040.
22. S. Karagoz, T. Bhaskar, A. Muto and Y. Sakata, Bioresour. Technol., 97, 90 (2006); https://doi.org/10.1016/j.biortech.2005.02.051.

23. W. Wang, Y. Xu, X. Wang, B. Zhang, W. Tian and J. Zhang, Bioresour. Technol., 250, 474 (2018); https://doi.org/10.1016/j.biortech.2017.11.051.

24. J. Sun, J. Yang and M. Shi, Transac. Tianjin Univ., 23, 301 (2017); https://doi.org/10.1007/s12209-017-0051-4.

25. R.L. Eager, J.F. Mathews, J.M. Pepper and H. Zohdi, Can. J. Chem., 59, 2191 (1981); https://doi.org/10.1139/v81-316. 